\title{
SEROPREVALENCE OF INFECTION WITH TOXOPLASMA GONDII AMONG THE RESIDENTS OF SOUTH BACKA DISTRICT, SERBIA
}

Ivana Hrnjakovic Cvjetkovic ${ }^{1,2^{*}}$, Vesna Milosevic ${ }^{1,2}$, Tamas Petrovic ${ }^{3}$, Dusan Petric ${ }^{4}$, Radovanov Jelena ${ }^{1}$, Kovacevic Gordana ${ }^{1}$, Patic Aleksandra ${ }^{2}$, Nikolic Natasa ${ }^{1,2}$, Nela Dopudj ${ }^{1}$, Sandra Stefan ${ }^{2,5}$, Dejan Cvjetkovic ${ }^{2,5}$

${ }^{1}$ Institute of Public Health of Vojvodina, Novi Sad, Serbia ${ }^{11}$

${ }^{2}$ University of Novi Sad, Faculty of Medicine Novi Sad, Novi Sad, Serbia

${ }^{3}$ Scientific Veterinary Institute "Novi Sad", Novi Sad, Serbia

${ }^{4}$ University of Novi Sad, Faculty of Agriculture, Novi Sad, Serbia

${ }^{5}$ University of Novi Sad, Faculty of Medicine, Clinical

Centre of Vojvodina, Novi Sad, Serbia

\section{Abstract}

Toxoplasma gondii is a ubiquitous coccidian protozoan that can infect a wide range of warm-blooded animals, including humans. For immunocompetent humans it is a well-adapted parasite that usually causes asymptomatic infection. However, in congenitally infected infants and immunocompromised patients it can cause a serious life threatening disease. The aim of this study was to determine the levels of anti-toxoplasma antibodies among residents of the South Backa District, Serbia. During the period from January 2014 to December 2018, sera from 11,288 persons from South Backa District were tested on the presence of IgM and IgG antibodies against Toxoplasma gondii, using ELISA test (Euroimmun, Lübeck, Germany). The testing was performed on the automatic device Euroimmun Analyzer I-2P. The avidity of IgG WNV antibodies was determined for IgG positive sera using commercial avidity test (Euroimmun, Lübeck, Germany). In total, out of 11,288 patients who were tested for toxoplasma antibodies, the results were positive for 2,513 (22.26\%). In 2014 seropositivity for Toxoplasma gondii was $25.78 \%$ (464/1800), in 2015 it was $23.30 \%$ (400/1717), in 2016 it amounted $20.99 \%$ (474/2258), in 2017 it was $21.47 \%(529 / 2464)$ and in 2018 seropositivity was $20.96 \%$ (639/3049). Seropositivity of $26.53 \%$ $(390 / 1470)$ was found in males and it amounted $21.62 \%(2123 / 9818)$ in

${ }^{1 *}$ Corresponding author: ivana.hrnjakovic-cvjetković@mf.uns.ac.rs 
females. Possible recent infection within the last 12 months was found in $1.70 \%(192 / 11288)$ patients. Possible acute infection or false - positive IgM result was detected in $1.31 \%(148 / 11288)$ patients. Past infection was found in $2173 / 11288(19.25 \%)$ patients. Equivocal results were found in $1.48 \%$ of samples (167/11288). The lowest frequency of anti-toxoplasma antibodies was detected in pre-school children $13.07 \%$ (97/742) and the highest in persons older than 65 years $60.18 \%$ (65/108). Comparing the results of the research done from 2014 to 2018 with the data from 1989, a significant decline of seroprevalence in general population and women of generative age was found.

Key words: Toxoplasma gondii, IgG ELISA, IgM ELISA

\title{
SEROPREVALENCA INFEKCIJE PROTOZOOM TOXOPLASMA GONDII U PRIPADNIKA POPULACIJE JUŽNO BAČKOG OKRUGA
}

\author{
Ivana Hrnjaković Cvjetkovićc ${ }^{1,2}$ Vesna Miloševićc ${ }^{1,2}$, Tamaš Petrovićc \\ Dušan Petrić ${ }^{4}$, Radovanov Jelena ${ }^{1}$, Kovačević Gordana ${ }^{1}$, Patić Aleksandra ${ }^{2}$, \\ Nataša Nikolićc ${ }^{1,2}$, Nela Dopudj ${ }^{1}$, Sandra Stefan ${ }^{2,5}$, Dejan Cvjetković ${ }^{2,5}$ \\ ${ }^{1}$ Institut za javno zdravlje Vojvodine, Novi Sad, Srbija \\ ${ }^{2}$ Univerzitet u Novom Sadu, Medicinski fakultet, Novi Sad, Srbija \\ ${ }^{3}$ Naučni institut za veterinarstvo "Novi Sad", Novi Sad, Srbija \\ ${ }^{4}$ Univerzitet u Novom Sadu, Poljoprivredni fakultet, Novi Sad, Srbija \\ ${ }^{5}$ Klinički centar Vojvodine, Klinika za infektivne bolesti, Novi Sad, Srbija
}

\section{Kratak sadržaj}

Toxoplasma gondii je široko rasprostranjena protozoa sposobna da inficira brojne toplokrvne životinje uključujući i ljude. Životni ciklus je kompleksan sa felidama kao definitivnim i toplokrvnim životinjama kao prelaznim domaćinima. Za imunokompetentne ljude to je prijateljski, dobro adaptiran parazit koji često izaziva asimptomatsku infekciju. Toksoplazmoza može biti teško, po život opasno oboljenje kod kongenitalno inficiranog ploda i imunodeficitarnih osoba. Kako je pokazano u različitim studijama učestalost infekcije toksoplazmom je različita. Cilj ove studije je bio da se odredi učestalost anti-toksoplazma antitela u stanovnika Južno 
Bačkog okruga, Srbija. U periodu od januara 2014.god do decembra 2018. god, serumi uzorkovani od 11288 osoba iz Južno Bačkog okruga su testirani na IgM i IgG antitela protiv Toxoplasmae gondii, ELISA testom (Euroimmun, Lübeck, Germany). Testiranje je sprovedeno na automatizovanom procesoru Euroimmun Analyzer I-2P. Aviditet IgG antitela za IgG pozitivne serume je testiran komercijalnim testom (Euroimmun, Lübeck, Germany). Od ukupno 11288 osoba koje su testirane na anti-toksoplazma antitela 2513 $(22,26 \%)$ su bile pozitivne. U 2014. godini u $25,78 \%$ (464/1800) uzoraka seruma dokazana su antitela na toksoplazmu, a u 2015. godini seropozitivnost je iznosila 23,30\% (400/1717), u 2016. godini 20,99\% (474/2258), u 2017. godini 21,47\% (529/2464) i u 2018. godini je bila 20,96\% (639/3049). Kod muškaraca je utvrđeno 26,53\% (390/1470) seropozitivnih dok je kod žena bilo 21,62\% (2123/9818) seropozitivnih. Moguća nedavna infekcija, tokom poslednjih 12 meseci je dokazana u 1,70\% (192/11288) osoba. Moguća akutna infekcija ili lažno pozitivan IgM rezultat je utvrđen kod 1,31\% (148/11288) osoba. Prošla infekcija je dokazana kod 2173/11288 $(19,25 \%)$ osoba. Granični rezultat je nađen u 1,48\% (167/11288) slučajeva. Najniža prevalenca anti-toksoplazma antitela je dokazana u predškolske dece $13,07 \%(97 / 742)$ a najviša u osoba starijih od 65 godina $60,18 \%$ (65/108). Poređenjem seroprevalence dobijene studijom iz 2018. sa rezultatima studije iz 1989. godine utvrđena je signifikantno niža prevalenca u studiji iz 2018. godine.

Ključne reči: Toxoplasma gondii, IgG ELISA, IgM ELISA

\section{INTRODUCTION}

Toxoplasma gondii is a ubiquitous coccidian protozoan that can infect a wide range of warm-blooded animals, including humans. The life cycle of this obligate intracellular parasite is complex. Domestic and wild members of the family Felidae are definitive host where it multiplies in the small intestine (sexual cycle). Humans and warm-blooded animals, including most livestock are intermediate hosts, where it forms a cyst in muscular and neural tissues. T. gondii causes zoonotic, cosmopolitan disease Toxoplasmosis. For immunocompetent humans it is a well- adapted parasite that causes asymptomatic infection in $10-20 \%$ cases according to studies conducted in USA and Europe. However, in congenitally infected infants and immunocompromised patients it can cause a serious life threatening disease. 


\section{MATERIAL AND METHODS}

The prevalence of anti-toxoplasma antibodies was determined retrospectively in 11,288 persons from South Bačka District, during a 5-year period (from January 2014 to December 2018). The analysed group included 9,818 females (aged 1 to 85) and 1470 males (aged 0 to 88). Among females, 9,113 (92.82\%) were childbearing women (defined in this paper as 19-45 year-olds). The serum samples were analysed for toxoplasma specific immunoglobulin $M$ (IgM) and G (IgG) antibodies, by ELISA IgG and ELISA IgM test (Euroimmun, Lübeck, Germany). The testing was performed on the automated device Euroimmun Analyzer I-2P at the Institute of Public Health of Vojvodina, Center of Virology. For determination of IgG avidity commercial ELISA using urea as a denaturing factor was carried out according to manufacturer's instruction (Euroimmun, Lübeck, Germany). A relative avidity index (RAI) was calculated and expressed as a percentile dividing the OD values with and without urea treatment.

\section{RESULTS}

During a 5-year period toxoplasma specific antibodies were found in 2,513 $(22.26 \%)$ out of 11,288 sera. Our results indicate that $76.26 \%(8608 / 11288)$ of tested persons were seronegative. In $1.48 \%$ (167/11288) of tested persons, equivocal results of serologic tests were found. In 2014 detected seropositivity for Toxoplasma gondii was $25.78 \%$ (464/1800), in 2015 it was $23.30 \%$ (400/1717), in 2016 was $20.99 \%$ (474/2258), and in 2017 seropositivity was detected in $21.47 \%$ (529/2464) and in 2018 in 20.96\% (639/3049) of tested persons. Seropositivity in 2014 was significantly higher than in $2016(\mathrm{p}=0.0004)$, in 2017 ( $\mathrm{p}=010011)$ and 2018 ( $\mathrm{p}=0.0001)$. Seropositivity of $26.53 \%(390 / 1470)$ was found in males while it was $21.62 \%(2123 / 9818)$ in females. The difference among male and female was statistically significant $(\mathrm{p}<0.0001)$.

Sole IgM positivity was found in $1.31 \%(148 / 11288)$, sole IgG positivity in $19.25 \%(2173 / 11288)$ and both IgM and IgG in 1.70\% (192/11288) of tested population of South Backa District (Table.1). Serologic profile of positive IgM anti-toxoplasma antibodies without IgG antibodies point to possible acute infection or false positive IgM result. 
Table 1. The presence of IgM, and IgG antibodies in sera of investigated persons, from 2014 to 2018

\begin{tabular}{cccc|cc|cc|c}
\hline \multirow{2}{*}{ Year } & \multirow{2}{*}{$\mathrm{N}$} & \multicolumn{2}{c}{$\begin{array}{c}\text { IgM positive } \\
\text { IgG negative }\end{array}$} & \multicolumn{2}{c|}{ IgM positive } & \multicolumn{2}{c}{ IgM negative } & Total \\
\cline { 3 - 9 } & & $\mathrm{n}$ & $\%$ & $\mathrm{n}$ & $\%$ & $\mathrm{n}$ & $\%$ & $\mathrm{n}$ \\
\hline 2014 & 1800 & 42 & 2.33 & 46 & 2.55 & 376 & 20.89 & 464 \\
\hline 2015 & 1717 & 13 & 0.75 & 40 & 2.33 & 347 & 20.21 & 400 \\
\hline 2016 & 2258 & 31 & 1.37 & 37 & 1.64 & 406 & 17.98 & 474 \\
\hline 2017 & 2464 & 38 & 1.54 & 48 & 1.95 & 443 & 17.98 & 529 \\
\hline 2018 & 3049 & 24 & 0.78 & 21 & 0.19 & 601 & 19.71 & 646 \\
\hline Total & 11288 & 148 & 1.31 & 192 & 1.70 & 2173 & 19.25 & 2513 \\
\hline
\end{tabular}

Legend: $\mathrm{N}$ total number of samples; $\mathrm{n}$ number of positive samples; IgM immunoglobulin M; IgG immunoglobulin G;

Possible recent infection within the last 12 months was found in $1.70 \%$ $(192 / 11288)$ patients in which both IgG and IgM antibodies were detected. In $2,173(19.25 \%)$ patients a serologic profile consistent with a past infection was found (only anti-toxoplasma IgG antibodies were positive). The results of Toxoplasma gondii seroprevalence in population of South Backa District by age group are shown in Table 2 .

In the youngest group (0-3 years) seroprevalence varied from 9\% (in 2015) to $18 \%$ (in 2016). In the eldest group seroprevalence varied from $47 \%$ (in 2016) to $68 \%$ (in 2014). We found that the seroprevalence for Toxoplasma gondii significantly increased with age.

In the population of South Backa District seroprevalence in childbearing women was $20.04 \%$ (1826/9113). Out of 9,113 childbearing women 101 (1.1\%) had serological profile consistent with possible recent infection within the last 12 months. In 20 childbearing women avidity of IgG was determined and RIA values were in the range from $61.2 \%$ to $97 \%$ indicating past toxoplasma infection in all tested childbearing women. 
Table 2. Toxoplasma gondii seroprevalence in population of South Backa District by age group

\begin{tabular}{lccccc}
\cline { 1 - 4 } $\begin{array}{c}\text { Year } \\
\begin{array}{c}\text { Age } \\
\text { group }\end{array}\end{array}$ & 2014 & 2015 & 2016 & 2017 & 2018 \\
\cline { 1 - 4 } $0-3$ & $15 \%(13 / 86)$ & $9 \%(9 / 98)$ & $18 \%(18 / 101)$ & $12 \%(11 / 88)$ & $17 \%(26 / 150)$ \\
\hline $4-6$ & $12 \%(6 / 48)$ & $11 \%(6 / 54)$ & $9 \%(4 / 45)$ & $0 \%(0 / 43)$ & $14 \%(4 / 29)$ \\
\hline $7-18$ & $27 \%(48 / 179)$ & $18 \%(36 / 198)$ & $22 \%(42 / 192)$ & $22 \%(33 / 148)$ & $19 \%(31 / 159)$ \\
\hline $19-25$ & $26 \%(56 / 212)$ & $26 \%(47 / 177)$ & $22 \%(47 / 213)$ & $21 \%(59 / 284)$ & $25 \%(93 / 377)$ \\
\hline $26-35$ & $\begin{array}{c}22 \% \\
(180 / 821)\end{array}$ & $\begin{array}{c}19 \% \\
(144 / 749)\end{array}$ & $\begin{array}{c}18 \% \\
(199 / 1093)\end{array}$ & $\begin{array}{c}20 \% \\
(231 / 1160)\end{array}$ & $\begin{array}{c}18 \% \\
(258 / 1451)\end{array}$ \\
\hline $36-45$ & $\begin{array}{c}29 \% \\
(101 / 348)\end{array}$ & $\begin{array}{c}29 \% \\
(96 / 336)\end{array}$ & $\begin{array}{c}22 \% \\
(113 / 513)\end{array}$ & $\begin{array}{c}22 \% \\
(146 / 648)\end{array}$ & $\begin{array}{c}22 \% \\
(164 / 742)\end{array}$ \\
\hline $46-55$ & $44 \%(18 / 41)$ & $52 \%(24 / 46)$ & $58 \%(28 / 48)$ & $42 \%(16 / 38)$ & $39 \%(22 / 57)$ \\
\hline $56-65$ & $64 \%(29 / 45)$ & $63 \%(26 / 41)$ & $44 \%(15 / 34)$ & $59 \%(19 / 32)$ & $42 \%(21 / 50)$ \\
\hline$>66$ & $68 \%(13 / 19)$ & $65 \%(11 / 17)$ & $47 \%(8 / 17)$ & $59 \%(13 / 22)$ & $61 \%(20 / 33)$ \\
\hline
\end{tabular}

\section{DISCUSSION}

Compared to other countries, a moderate seroprevalence (22.26\%) for anti-Toxoplasma specific antibodies was found in our study in South Backa District. The highest seroprevalences of toxoplasmosis were detected in tropical areas in Africa (14\%-78\%), Brazil (75\%) and Ethiopia (73\%). The lowest seroprevalences of toxoplasmosis were observed in hot and dry area in Asia (Foroutan-Rad M, 2016). In Chinese blood donors the overall IgG seroprevalence of T. gondii infection was low 6.26\% (Wang et al., 2018). Seroprevalence of $24.2 \%$ (123/508), similar to that detected in our study, was found in a healthy population of Slovakia (Studeničová et al., 2006). In a study of Coroiu and co-workers (2009), the seroprevalence for T. gondii in general population of north-western and central Romania were higher, amounting 59.4\% (686/1155). In serological study conducted in Germany seroprevalence of 55\% (3602/6564) was found (Wilking et al., 2016). The results of many studies of Toxoplasma gondii infection in humans showed different rates of seroprevalence depending on geographical location, environment, socio-economic, culinary habits and applied diagnostic methods.

In the study conducted in 1989, we tested 1000 serum samples of person from South Backa District applying immunofluorescent test for anti-toxoplas- 
ma IgG and IgM antibodies (Hrnjakovic Cvjetkovic, 1989). Comparing the data of these two studies we found that seroprevalence was decreasing from $30.70 \%$ in 1989 to $22.26 \%$ in 2018 ( $\mathrm{p}<0.0001)$. Generally, a decrease in the number of seropositive humans and animals had been detected in many European countries and USA over the last few decades. In the study comparing the U.S. prevalence of T. gondii infection in humans during period 1988-1994 and 1999-2004, a decrease from $14.1 \%$ to $9.0 \%$ in 6 to 49 year-olds was found (Jones et al., 2007). The T. gondii overall seroprevalence decreased from $47 \%$ in $1979 / 1980$ to $22 \%$ (95\% CI $20 \%$ to $24 \%$ ) in the Portuguese population in 2013 (Gargaté et al, 2016). In our study seroprevalence increased with age from $15 \%$ in the age group of 0 to 3 year-olds to $60 \%$ in the age group $>65$ years like in other similar studies (Wilking et al., 2016; Studeničová et al., 2006; Gargaté et al., 2016).

Seroprevalence in childbearing women found in this study was $20.04 \%$ (1826/9113) and it differs from older data from our country. Among women of reproductive age, in the area of Belgrade, during the 1988-1991 period, the rate of infection with Toxoplasma gondii was 77.4\% (Bobić et al., 1998). In women of childbearing age in the period from 1990 to 2000 seroprevalence were 11\% in Norway, 14\% in Sweden and 8\% in East England. (Tenter et al., 2000; Petersson et al., 2000)

Comparing seroprevalence in childbearing women in 2014-2018 (20.04\%) with seroprevalence in 1989 (33.48\%) (Hrnjakovic Cvjetković, 1989), we found that seroprevalence in South Backa District significantly decreased over time. The similar trend was noticed in the studies on seroprevalence of childbearing women from Portugal (Gargaté et al., 2016).

Possible recent infection within the last 12 months of $1.1 \%$ was determined in this study of 9,113 women of childbearing age. In the study of Mumcuoglu et al. (2014) $0.9 \%$ out of 4,758 pregnant women had the serological profile consistent with possible recent infection. In the study of Stojanovic (1998), acute toxoplasma infection was registered in $0.61 \%$ of 1,266 pregnant women in Timok region in 1998.

Due to acquired data on seroprevalence, out of $22.26 \%$ in this study, South Backa District is listed among regions of moderate seroprevalence in respect of toxoplasmosis. In the time period from 2016 to 2018, seroprevalence of toxoplasmosis declined significantly in comparison to its values in 2014. Comparing the results of the research performed from 2014 to 2018 with the data from 1989 , there is a significant decline of seroprevalence in general population and women at generative age, which is in compliance with the studies conducted in the USA and the EU. 


\section{ACKNOWLEDGEMENT}

This work is conducted within the projects TR31084 and III43007 funded by the Serbian Ministry of Education, Science and Technological development

\section{REFERENCES}

1. Bobić B., Jevremović I., Marinković J., Šibalć D., Djurković Djaković O. 1998. Risk factors for Toxoplasma infection in a reproductive age female population in the area of Belgrade Yugoslavia. European Journal of Epidemiology, 14, 605-610;

2. Coroiu Z., Radu R., Molnar A., Bele, J. 2009. Seroprevalence of antiToxoplasma gondii antibodies in the healthy population from northwestern and central Romania. Scientia Parasitologica 1, 37-42;

3. Foroutan-Rad M., Majidiani H., Dalvand S., Daryani A., Kooti W., Saki J., Hedayati-Rad F., Ahmadpour E. 2016. Toxoplasmosis in Blood Donors: A Systematic Review and Meta-Analysis.Transfusion Medicine Reviews, 30, 3, 116-22;

4. Gargaté M.J., Ferreira I., Vilares A., Martins S., Cardoso C., Silva S., Nunes B., Gomes J.P. 2016. Toxoplasma gondii seroprevalence in the Portuguese population: comparison of three cross-sectional studies spanning three decades BMJ Open, 6:e11648;

5. Hrnjakovic Cvjetkovic I. 1989. Problem toksoplazmoze i njene laboratorijske dijagnostike, Magistarski rad, Medicinski fakultet Novi Sad, 88;

6. 6. Jones J.L., Kruszon-Moran D., Sanders-Lewis K., Wilson M. 2007. Toxoplasma gondii Infection in the United States, 1999-2004, American Journal of Tropical Medicine and Hygiene, 77, 3, 405-410;

7. Mumcuoglu I., Toyran A., Cetin F., Coskun FA., Baran I., Aksu N., Aksoy A. 2014. Evaluation of the toxoplasmosis seroprevalence in pregnant women and creating a diagnostic algorithm. Mikrobiyoloji Bülteni, 48, 2, 283-91;

8. Petersson K., Stray-Pedersen B., Malm G., Forsgren M., Evengård B. 2000. Seroprevalence of Toxoplasma gondii among pregnant women in Sweden. Acta Obstet Gynecol Scand, 79, 10, 824-9;

9. Stojanovic D. 1998. The effect of toxoplasmosis on occurrence of spontaneous abortions and anomalies in neonates in the Timok region. Vojnosanitetski Pregled, 55, 2, 151-9;

10. Studeničová C., Benčaiová G., Holková R. 2006. Seroprevalence of Toxoplasma gondii antibodies in a healthy population from Slovakia. Europian Journal of Internal Medicine, 17, 7, 470-473; 
11. Tenter A.M., Heckeroth A.R., Weiss L.M. 2000. Toxoplasma gondii: from animals to humans. International Journal for Parasitology, 30, 12-13, 1217-1258;

12. Wang T., Han Y., Pan Z., Wang H., Yuan M., Lin H. 2018. Seroprevalence of Toxoplasma gondii infection in blood donors in mainland China: a systematic review and meta-analysis. Parasite, 25, 36. Published online $2018 \mathrm{Jul}$ 23, doi: 10.1051/parasite/2018037;

13. Wilking H., Thamm M., Stark K., Aebischer T., Seeber F. 2016. Prevalence, incidence estimations, and risk factors of Toxoplasma gondii infection in Germany: a representative, cross-sectional, serological study. Scientific Reports, 6, 22551, Published online 2016 Mar 3. doi: 10.1038/srep22551;

Submitted: 11.04.2019. Accepted: 02.06.2019. 